Научная статья

УДК 291.1:004.9:316.74:316.775

DOI: 10.18101/1994-0866-2021-4-11-17

\title{
РЕЛИГИЯ В СИТУАЦИИ ПОСТПОСТМОДЕРНИЗМА
}

\section{(C) Багаева Ксения Анатольевна}

кандидат философских наук, доцент кафедры философии, Бурятский государственный университет имени Доржи Банзарова Россия, 670000, г. Улан-Удэ, ул. Смолина, 24 а ksyusha.81@mail.ru

\begin{abstract}
Аннотация. В научной литературе можно обнаружить различные попытки определить современное состояние культуры. В качестве примеров рассмотрены предлагаемые теоретиками термины как альтермодерн и трансмодерн. Автор приводит основания, которые позволяют определять современную эпоху как постпостмодернизм. В рамках постпостмодернисткого дискурса в статье рассматриваются постсекулярное общество, особенности существования в нем религии. Основываясь на дефиниции постпостмодернизма, автор формулирует особенности трансформации религии, связывая это с наступлением постсекуляризма. Также в статье указывается, что главной особенностью постпостмодернизма является его технологичность, виртуализированность, транссентиментализм. Такие специфические черты постпостмодернизма привели к медиатизации религии, появлению религиозных цифровых практик. Религия активна в медиапространстве - есть религиозные блоги, платформы, веб-сайты. Таким образом, религиозное пространство видоизменяется, усложняется и фрагментируется в информационном пространстве.

Ключевые слова: религия, постсекулярное общество, постпостмодернизм, постмодернизм, модернизм, интернет, общество, трансформация.
\end{abstract}

\section{Для цитирования}

Багаева К. А. Религия в ситуации постпостмодернизма // Вестник Бурятского государственного университета. Философия. 2021. Вып. 4. С. 11-17.

В социальной мысли сложилось устойчивое мнение, что религия консервативный социальный феномен, который долго и с трудом подвергается модернизации. Однако современное положение религии доказывает обратное, когда мы наблюдаем изменение религии, появление ее в публичном пространстве.

Трансформацию религии описывают в разных терминах. Так, до 90-х гг. в $\mathrm{XX}$ в. использовался термин «квазирелигия». Авторами данных определений были зарубежные исследователи, создатели классических концепций квазирелигии Пауль Тиллих [1], Джон Смит [2]. Также надо отметить более поздних исследователей, таких как Артур Грил [3], понимающий под квазирелигиями феномены, находящиеся между сакральным и профанным, которые проявляются в американском обществе. Другой исследователь Джефри Хедден связывает появление феномена квазирелигий с возникновением новых религиозных движений [4]. В данном контексте употребление приставки «квази» и связанные с ним такие понятия, как «квазирелигиозность», «квазивера», означают изменение, трансформацию религии под эгидой светского начала. Религиозное значение уходит 
на второй план и проявляются политические, экономические, социальные, этнические основания.

На рубеже XX-XXI вв. в научный оборот вводятся новые термины, например, Кристофер Хэлланд использует «онлайн-религию» как некую информацию о религии в интернет-пространстве и как особую форму взаимодействия и коммуникации, что создает возможность создания конфессиональных интернетсообществ. Последние дают возможность для верующих ощутить сопричастность, виртуально участвовать в молитвах, совершать ритуалы [5]. Таким образом, появляется совершенно новый вид религиозного взаимодействия в сети, который сегодня становится наиболее актуальным. Подобным значением наделяют и термин «киберрелигия» в своей монографии «Киберрелигия: наука как фактор религиозных трансформаций» А. П. Забияко, Е. А. Воронкова, А. В. Лапин, Д. А. Пратына и др. [6, с. 25].

Множество разных терминов свидетельствует и о разном понимании трансформации религии. Другое дело, что текущая трансформация отличается от тех изменений, которые происходили в религии в конце XX в. Поэтому целью исследования становится определение особенностей религии в данный момент.

Обращаясь к истории человеческой культуры, мы видим, что религия всегда была рядом с человеком вплоть до того, что занимала доминирующие позиции в мировоззрении. Такая ситуация продолжалась до начала эпохи модерна, которая связывается с процессом секуляризации и ослабления влияния религии в обществе. Но, события конца XX в., произошедшие в Европе, США, России (политизация ислама, возрождение религии в России, активизация новых религиозных движений), показали необходимость ревизии секуляристкой позиции. Результатом переосмысления секуляризации стали теоретические модели, начиная от теории десекуляризации П. Бергера [7, с. 8-20 ] и заканчивая постсекулярным миром Ю. Хабермаса [8, с. 1-2].

Начиная с XVII в. перманентный процесс секуляризации не прерывался в течение долгого времени, однако весь ход современной новейшей истории показал отмирание секуляризации. Жесткая идеологическая позиция сменилась на плюралистичную методологию постсекуляризма, которая привела к переосмыслению места религии в обществе. Современное общество - это общество постсекулярное, как определяет его Ю. Хабермас [8, с. 1-2]. Термин «постсекулярный» начинает использоваться научной литературе с конца 90-х гг. ХХ в. Считается, что постсекулярное общество сменило секуляризованное общество, возникшее в результате модернизации, рационализации, роста научного знания. Секуляризация привела к вытеснению религии из публичного социального пространства. Сегодня же мы наблюдаем очевидную ситуацию, когда религия «возвращается». Модерн изгнал религию из публичного социального пространства и привел к секуляризации, постмодерн возвратил религию в социальные отношения. В настоящее время отмечается совершенно другая ситуация, когда религия входит в виртуальное пространство.

Постсекулярное как установка означает не просто выход религии за пределы религиозного, но и нахождение религией новых сфер и пространств для своего существования. В рамках распада модернизма и перехода к постмодернизму изза пошатнувшейся позиции рационалистической философии стало возможным 
говорить о постсекулярном. Если секуляризм задавал определенные границы религии, то постсекуляризм отвергает их. Поэтому представляется верным утверждать, что в современном постсекулярном обществе одной из сфер существования религии является медиапространство. Если в понимании Ю. Хабермаса постсекулярное общество становится таковым, когда принимает нахождение религии в социальном безоговорочно [8, с. 1-2], то католические теологи как Дж. Милбэнк [9] и М. Кинг [10] считают, что «постсекулярный путь» видится ими как путь новой духовности, примирение науки и религии, разума и веры. Что и происходит сейчас в виртуальном пространстве.

С конца 80-х гг. прошлого века теоретики начинают прощаться с посмодернизмом, но окончательно власть постмодернизма закончилась в 2000-х гг., ключевой фигурой этого события стала Линда Хатчеон, написав: «Постпостмодернизм нуждается в новом собственном ярлыке, и я подвожу итог: бросаю вызов читателям самостоятельно найти его и дать ему имя собственное в двадцать первом веке», и именно она выявила в постмодернизме неспособность объять рост информационных технологий [11, p. 181].

Отметим, что наступившая реальность после постмодернизма имеет ряд спорных названий. Французский философ Николя Буррио вводит термин «альтермодерн», который означает некоторую ситуацию пограничного состояния, как продолжение модерна, но через упрощение всего и ведет к созданию универсальной гомогенной культуры [12]. Так, аргентинский теолог Энрике Дуссель считает, что сегодня наступила эпоха трансмодерна, соединяющая в себе черты модерна и постмодерна, причиной которого стала глобализация, когда объединяются в единое целое социальные сообщества, не только европейские, которые и становятся центром внимания, а не человек [13]. Кроме того, есть термины «гипермодернизм», «метамодернизм», «космодернизм» и многое другое. Однако значительным минусом указанных определений является их не обращение к информационным технологиям. В этом смысле заслуживает внимание термин отечественных исследователей «потспостмодернизм», который считаем более соответствующим происходящим событиям в действительности, как что-то пришедшее вслед за постмодернизмом. Большинством исследователей постпостмодернизм используется как зонтичный термин, объединяющий в себе указанные определения, понятия и направления. Один из теоретиков постпостмодернизма в искусстве Н. Маньковская указывает: «Виртуальная реальность в искусстве созданная компьютерными средствами искусственная среда, в которую можно проникать, меняя ее изнутри и испытывая при этом реальные ощущения. Попав в этот новый тип аудиовизуальной реальности, можно вступать в контакты не только с другими людьми, также внедрившимися в нее, но и с искусственными персонажами» [14, с. 20]. Информационные технологии, цифровые устройства сегодня формируют социальность и трансформируют нашу повседневность, оказывая влияние на все сферы общества. Новые технологии изменили социальные отношения, поэтому одной из особенностей современной реальности становится то, что религия действует в виртуальной реальности. Одной из характеристик религии является наличие мира земного и мира небесного, мир удваивается в религиозном сознании, теперь же удвоение реальности происходит и через интернет. 
Постпостмодерн сменил постмодерн, который уже не успевает за всем тем, что происходит и произошло в культуре. Поэтому главной особенностью трансформации религии является ее существование в виртуальной реальности. Если ранее религия конструировала осмысленный мир для человека, освящала социальность религиозными ценностями, то сейчас совершенно новая реальность, к которой религия успешно адаптируется и формирует там религиозные смыслы. Модерн вытеснил религиозное из публичного пространства сделав его сферой приватного, постмодернизм привел к формированию постсекулярного мира, а постпостмодернизм благодаря технологиям вывел религию в цифровой формат.

Вообще дихотомия «модерн - постмодерн» в большей степени присуща для западноевропейской культуры, потому что секуляризация и последующий за ней модернизм проявились в Европе и по большей части связаны с христианством и его ролью, соответственно логично пришли к постмодернизму. Тогда как наблюдаемая ситуация постпостмодерна охватывает и восточные культуры, соответственно ислам и буддизм также включаются в фокус событий, ведь именно они сегодня достаточно способны к трансформациям. Поэтому постпостмодернизм более широк по своему охвату. Поэтому обращение к постмодерну для характеристики изменений современной религии становится не актуальным. Поэтому О. А. Митрошенков пишет, что «исчерпание постмодернистского импульса произошло быстро - уже в середине 1990-х гг. ситуация стала переопределяться в разных измерениях: технологически (интернет стал мощным и значительным фактором социальной жизни); политически (теоретический и практический крах влиятельного ранее неолиберализма был признан практически повсеместно); социально (радикализация среднего класса, рекрутируемого прежде всего из среды «массового человека», который, в свою очередь, в отдельных отношениях преодолевает свои худшие черты и обретает идентичность более высокого порядка); культурно (актуализация фундаментализма, причем не столько религиозного, сколько экзистенциального, обращенного к надежным и понятным нормам и ценностям); эстетически (новый натурализм, воскресший неоакадемизм)» [15, c. 127]. Основными компонентами постпостмодернизма являются четыре аспекта: виртуализация, технообразы, глокализация и транссентиментализм. Два первых аспекта оказывают непосредственное влияние на религию. Медиа прочно вошли в ткань религии, поэтому возможно говорить о ее медиатизации. Как верно еще отмечал Н. Луман: «массмедиа являются одной из функциональных систем современного общества, которая, подобно всем остальным, своей усиливающейся производительностью обязана своему системному обособлению, оперативной замкнутости и аутопойетической автономии» [16, с. 11].

Технические устройства, такие как ноутбуки, смартфоны, планшеты и другие, прочно вошли в нашу жизнь, они обладают множеством функций, удобны и компактны и в то же время они становятся средоточием социальной жизни, в том числе и религиозной. Теперь можно самим регулировать наполнение совей социальной жизни взмахом пальца по сенсорному экрану устройства. Таким образом, используя терминологию Ж. Бодрийяра, формируется симулякр [17], т. е. симуляция действительности, в данном случае симуляция религии, ее ценностей, выполнение практик, молитв в виртуальном пространстве. И картина мира, порождаемая массмедиа, становится симулякром. В постпостмодернисткой реальности 
при достаточно большом покрытии интернетом каждый человек становится участником любого религиозного события посредством комментарием, лайков и перепостов. Тем самым каждый пользователь ощущает свою сопричастность и вовлеченность в религиозное действо, будь то это молитва или лекция. Отметим, что сегодня религия в медиапространстве изменяется, ведь появляются новые технологии и возможности, форматы и способы подачи информации. Одним из важнейших аспектов трансформации является интерактивность. Когда последователь комментирует и обсуждает новость, тем самым он дополняет событие своим сообщением, создавая таким образом технообраз. Это объект, созданный независимо одним автором, но в то же время поддерживаемый другими пользователями и становящийся объектом социального действия. Таким образом, формируется виртуальная реальность, в которой люди ведут в том числе свою социальную жизнь. Религия обретает симуляционный характер, сакральные смыслы виртуализируются, становятся общедоступными в любой точке мира благодаря интернету. Транссентиментализм со своей аксиологической установкой на приоритет вечных ценностей, включающих и религиозно-нравственные ориентиры, также укладывается в постпостмодернисткую составляющую религии. Характерная для постмодерна ирония уходит в прошлое.

Итак, медиатизированная религиозная жизнь - это главная особенность религии в ситуации постпостмодернизма. Новые технологии изменили ткань социальных отношений. Высокотехнологичная глобализация привела к тому, что присутствие религии в виртуальном пространстве - это обыденность. Постмодерн создал благоприятную почву для расцвета религии, потому как он усомнился в истинности критиковавшего религию модерна и подорвал авторитет науки. И реальность происходивших религиозных событий и религиозного подъема, появления новых религиозных движений в XX в. доказывает легитимацию религии постмодерном. В целом именно постмодернизм подготовил великолепную почву для выхода религии в новую реальность, так как уровнял религию и светское мировоззрение. Проблема поиска истинного мировоззрения в постмодернизме оборачивается поиском интерпретации. Посмодернизм создал условия для общедоступности религии, ее практик, учений, культов. Для человека молитва, поход в церковь, дацан становится повседневным и обыденным, теперь вера это личный выбор каждого. Постмодерн подготовил почву для постсекулярного общества, когда можно отойти от религиозных клише и стереотипов. В конце концов, с одной стороны, это привело к религиозным исканиям, усилении традиционных религий, проявлению религиозного фундаментализма, а с другой - к возможности для религии уйти со своего обычного места. Наконец в настоящей постпостмодернисткой эпохе «перезагрузка» религии проявилась в виртуальном пространстве и формировании новых цифровых форм религии. Создаваемые медиаобразы религии становятся социальными аттракторами и нередко формируют информационные потоки, захватывая и сознание, и культуру. Пришедший на смену модерну и секуляризации постмодернизм с постсекуляризмом вызвал начало постпостмодернизма и появление новой медиарелигии. 
Лumepamypa

1. Тиллих П. Христианство и встреча мировых религий // Избранное: Теология культуры. Москва: Юрист, 1995. 479 с. Текст: непосредственный.

2. Smith J. E. Humanism as a Quasi-Religion // Free Inquiry. Fall. 1996. Vol. 16. P. 17-20.

3. Greil A. L., Robbins T., eds. Between Sacred and Secular: Research and Theory on Quasi Religion. Greenwich, CT: JAI Press, 1994. 321 p.

4. Hadden J. K. Toward Desacralizing Secularization Theory // Social Forces. 1987. Vol. 65, № 3. P. 587-611.

5. Helland Christopher. Surfing for Salvation // Religion. 2002. 32. P. 293-303.

6. Киберрелигия: наука как фактор религиозных трансформаций / А. П. Забияко, Е. А. Воронкова, А. В. Лапин [и др.]; под редакцией А. П. Забияко. Благовещенск: Изд-во Амур. гос. ун-та, 2012. 208 с. Текст: непосредственный.

7. Бергер П. Фальсифицированная секуляризация // Государство, религия, церковь в России и за рубежом. 2012. № 2. С. 8-20. Текст: непосредственный.

8. Хабермас Ю. Постсекулярное общество - что это? Часть первая // Российская философская газета. 2008. № 4(18). С. 1-2 Текст: непосредственный.

9. Milbank J. Theology and Social Theory: Beyond Secular Reason. Oxford-Cambridge, 1990. 448 p.

10. King M. Postsecularism: the Hidden Challenge to Extremism. Cambridge, 2009. 324 p.

11. Hutcheon L. The Politics of Postmodernism. N. Y.; L., 2002. 402 p.

12. Bourriaud N. Relational Aesthetics. Dijon, 2002. 124 p.

13. Dussel E. Philosophy of Liberation. Wipf \& Stock Publishers, 2003. 224 p.

14. Маньковская Н. От модернизма к постпостмодернизму via постмодернизм // Коллаж-2. Москва: ИФ РАН, 1999. С. 18-25. Текст: непосредственный.

15. Митрошенков О. А. Что придет на смену постмодернизму // Свободная мысль. 2013. № 3(1639). С. 125-131. Текст: непосредственный.

16. Луман Никлас Реальность массмедиа / перевод с немецкого А. Ю. Антоновского. Москва: Праксис, 2005. 256 с. Текст: непосредственный.

17. Бодрийяр Ж. Симулякры и симуляции / перевод О. А. Печенкина. Тула: Тульский полиграфист, 2013. 204 с. Текст: непосредственный.

Статья поступила в редакиџю 02.11.2021; одобрена после рецензирования 11.11.2021; принята к публикации 15.11.2021.

\section{RELIGION IN THE SITUATION OF POST-POSTMODERNISM}

Ksenia A. Bagaeva

Cand. Sci. (Phil.), A/Prof. of Philosophy Department, Dorzhi Banzarov Buryat State University

24a Smolina St., Ulan-Ude 670000, Russia ksyusha.81@mail.ru

Abstract. Various authors have taken different approaches in an attempt to determine the current condition of culture. We have considered as examples the terms "altermodern" and "transmodern" proposed by theorists, and gave reasons that allow defining the modern age as post-postmodernism. The article analyzes the post-secular society, the peculiarities of religion in it from the perspective of post-postmodern discourse. Based on the definition of post-postmodernism, we have revealed the features of religion transformation associated 
with the advent of post-secularism. The article also emphasizes that the key features of postpostmodernism are its technological capabilities, virtualization, trans-sentimentality. Such specifities of post-postmodernism led to mediatization of religion, and emergence of religious digital practices. Religion is active in the media space - there are religious blogs, platforms, websites. Thus, the religious space is being modified, complicated and fragmented in the information space.

Keywords: religion, post-secular society, post-postmodernism, postmodernism, modernism, internet, society, transformation.

For citation

Bagaeva K. A. Religion in the Situation of Post-Postmodernism. Bulletin of Buryat State University. Philosophy. 2021; 4: 11-17.

The article was submitted 02.11.2021; approved after reviewing 11.11.2021; accepted for publication 15.11.2021. 